\title{
Hybrid and Electric Automotive Systems: Combined Electrical, Mechanical, and Fuel Cell Opportunities for Personal Transportation
}

\author{
Philip T. Krein
}

\begin{abstract}
Electric automobiles are clean, efficient, and powerful but are limited in range. Hybrid designs seek to enhance range through the use of liquid fuel. The energy, force, and power needs of a typical car are reviewed. The relationship to fuel cells as energy sources is discussed. Opportunities in the electrical arena, the mechanical arena, and the fuel cell arena are presented. Two commercial hybrid vehicle examples are presented. The convergence of developments in these areas will dominate hybrid designs as commercial production continues to ramp up.
\end{abstract}

\section{INTRODUCTION}

This paper is based on [1], in which the sequence of developments in hybrid electric vehicles is described. Added to the discussion of [1] is an overview of key challenges that need to be addressed as modern electric and hybrid vehicles continue to develop. Much present work seeks to develop fuel cells for primary automotive energy, and this recent work motivates a discussion of electrical, mechanical, and fuel cell challenges that will influence electric and hybrid vehicle design through about 2015.

Electric automobiles led the development of other vehicles, appearing by the 1990s and peaking in production after 1910 [2]. The vehicles were clean, easy to use, and required much less maintenance than the gasoline and steam vehicles of the day. Hybrid electric vehicles also appeared very early. Ferdinand Porsche's early design [3], which can be observed at [4], dates from 1900. It used an engine-generator set, and had electric motors in the wheels for traction. No gear shifting was needed. Both electric and hybrid architectures became less popular as the technologies of fuel-driven engines evolved. Many authorities argue that low fuel cost and the rapid acceptance of the mass-produced Ford Model $\mathrm{T}$ led to their decline and virtual disappearance in the 1920s [5].

Hybrid vehicle technology held its ground in larger applications, and remains a significant industrial transportation system today. The diesel-electric locomotive appeared in the 1920s. It uses a large diesel engine to drive an electric generator. Power from the generator is controlled and delivered to electric motors that provide motive force. Many ships, submarines, and large off-road trucks use the same architecture.

Grainger Center for Electric Machinery and Electromechanics

Department of Electrical and Computer Engineering

University of Illinois, Urbana, Illinois USA, machines@ece.uiuc.edu

The paper is an invited paper to the Journal and was prepared as part of the Distinguished Lecturer Program of the IEEE Power Electronics Society. A previous version was presented in [1] and second talent on International Conference on Power Electronics Systems and Applications 2006.
}

Diesel-electric hybrids exhibit the key advantages of a hybrid configuration:

- On-board energy is stored as liquid fuel, with energy per unit mass far greater than batteries, flywheels, or other storage approaches.

- Mechanical energy is converted directly to electric form with no adjustable gearboxes, drive shafts, linkages, or other large mechanical connections.

- The engine can operate near its most efficient conditions since it is decoupled from user needs.

- Energy conversion in electric machines is efficient, with excellent power-to-weight ratio and flexible control.

Thus diesel-electric hybrids remain the transportation system of choice at levels of about $500 \mathrm{~kW}$ and higher.

\section{ENERGY, POWER AND FORCE NEEDS}

Energy, power and force requirements dominate many design choices in electric and hybrid vehicles. In an electric car, for example, range is governed by stored energy. Key figures of merit for energy storage include energy per unit mass and power per unit mass. Energy per unit volume can also be important, as in vehicles that use on-board hydrogen fuel. Table I provides a summary based on energy for a few major storage technologies.

Table 1: Energy Storage Technology Comparison

\begin{tabular}{lll}
\hline \multicolumn{1}{c}{ Storage technology } & Mass density & Volume density \\
\hline Lead-acid batteries & $100 \mathrm{~kJ} / \mathrm{kg}$ & \\
Compressed air, 10 & $80 \mathrm{~kJ} / \mathrm{kg}$ & \\
MPa & & \\
Electrolytic capacitors & $0.2 \mathrm{~kJ} / \mathrm{kg}$ & \\
Double-layer & $20 \mathrm{~kJ} / \mathrm{kg}$ & \\
capacitors & & \\
Lithium-ion batteries & $600 \mathrm{~kJ} / \mathrm{kg}$ & \\
Gasoline & $43000 \mathrm{~kJ} / \mathrm{kg}$ & $29000 \mathrm{~kJ} / \mathrm{L}$ \\
Hydrogen(liquid) & $120000 \mathrm{~kJ} / \mathrm{kg}$ & $8000 \mathrm{~kJ} / \mathrm{L}$ \\
\hline
\end{tabular}

The values in Table I show why batteries have long been the storage approaches for electric cars: even conventional lead-acid cells store much more energy per unit mass than mechanical and electrical alternatives. Even taking into account the limited thermal efficiency of fuel processes, gasoline stores about 100 times as much useful energy per unit mas as lead-acid batteries, and about 20 times as much as energy-dense lithium-ion cells. Hydrogen stores more energy per unit mass than any other fuel, but its low mass density limits its value as a transportation energy storage method. 
In terms of power, the process of refueling delivers energy at extraordinary rates. For example, if a fuel tank with capacity of $60 \mathrm{~L}$ is filled in five minutes, the effective energy transfer rate is $6 \mathrm{MW}$. With batteries, rates are limited, and mass power density is an important figure of merit. Conventional batteries are hard pressed to deliver more than $500 \mathrm{~W} / \mathrm{kg}$, and even the best designs are unlikely to deliver more than $1000 \mathrm{~W} / \mathrm{kg}$. Power density is often a key limiting factor in hybrid vehicle design. A hybrid design rated for $100 \mathrm{~kW}$ of peak power would require at least $200 \mathrm{~kg}$ of batteries just to support this energy rate.

Force requirements for automobiles can be computed from well-known relationships [6]. Table 2 lists several computed results, based on methods in [6], for a conventional car and estimated for the General Motors EVl electric commuter vehicle. The results show a wide gulf between continuous power requirements under benign conditions and peak power requirements for aggressive acceleration.

Table 2: Force and Power Needs of Two Vehicles

\begin{tabular}{|c|c|c|}
\hline Requirement & $\begin{array}{l}\text { Need, } 1800 \mathrm{~kg} \\
\text { car }\end{array}$ & Need, EV1 \\
\hline Move on $25 \%$ grade & $4600 \mathrm{~N}$ thrust & $3800 \mathrm{~N}$ \\
\hline $\begin{array}{l}100 \mathrm{~km} / \mathrm{h} \text { cruise, level } \\
\mathrm{road}\end{array}$ & $11 \mathrm{~kW}$ & $8 \mathrm{~kW}$ \\
\hline $\begin{array}{l}\text { Maintain } 100 \mathrm{~km} / \mathrm{h} \text {, } \\
5 \% \text { grade }\end{array}$ & $36 \mathrm{~kW}$ & $29 \mathrm{~kW}$ \\
\hline $\begin{array}{l}\text { Peak acceleration, 0- } \\
95 \mathrm{~km} / \mathrm{h}\end{array}$ & $\begin{array}{l}80 \mathrm{~kW} \quad \text { (time } \\
12 \mathrm{~s})\end{array}$ & $102 \mathrm{~kW}(11 \mathrm{~s})$ \\
\hline
\end{tabular}

The pinnacle of electric vehicle redevelopment has been the General Motors EV1, a two-seat electric sports car with exceptional performance. A view is provided in Fig. 1 [7]. Although this vehicle generated wide interest and consumer demand, it was never seriously marketed by General Motors. The vehicles were recalled when difficulties appeared with the battery chargers, and apparently nearly all have since been destroyed by the manufacturer.

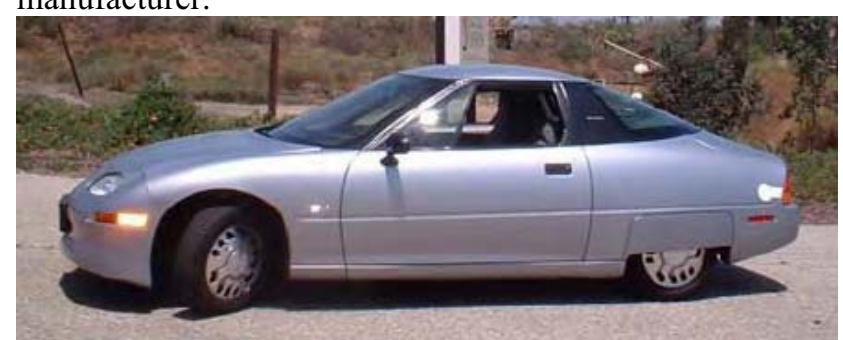

Fig.1: General Motors EV1 vehicle (used with permission of B. Waddell [7]).

The EV1 showed the promise of modern electric vehicle designs:

- A small induction motor was able to deliver $102 \mathrm{~kW}$ in a tight traction package, and set a new standard for traction power-to-weight ratio.

- supported smooth operation and high torque. A modified EV1 set the land speed record for electric vehicles.

- A paddle-style contactless charging system showed new ways to manage electrical safety.
- Energy recovery during braking was smooth and efficient.

- Consumers who tested the car were invariably impressed by the performance, quietness, and smooth operation.

The drawback was the heavy battery pack. Even with almost $600 \mathrm{~kg}$ of batteries, the typical range was less than $150 \mathrm{~km}$. Although this range is adequate for many commuters, it was thought to be too low for mass markets.

Improvements in lithium-ion batteries are encouraging further consideration of all-electric cars [8]. Even the best batteries, however, are unlikely to store more than $300 \mathrm{~W}$ $\mathrm{hr} / \mathrm{kg}$ (about $1000 \mathrm{~kJ} / \mathrm{kg}$ ). In principle, lithium batteries support most commuting needs. If rapid recharge becomes feasible, long trips might be within reach of the technology, but for the foreseeable future, energy storage remains the limiting factor for electric cars.

Since the force and power requirements in Table II are not especially difficult for electric vehicles, hybrid vehicles seek to apply electric drives but store energy as a liquid fuel. Good hybrid vehicle designs today can achieve approximately double the fuel economy of equivalent conventional cars. Perhaps more significant is the impact on tailpipe emissions. A hybrid design has at least five characteristics that reduce emissions:

1. The engine can be smaller since the electric motor can assist during peak requirements.

2. The engine can shut off when the car stops.

3. The engine can be controlled to operate only near an optimum emissions condition.

4. Stored battery energy can be used to prepare the emission system for cold starts.

5. Braking energy can be recovered and stored.

In addition, efficient engines not well-suited to direct use can be applied. The Toyota Prius, for instance, uses an Atkinson Cycle engine that is slightly more efficient than a conventional Otto Cycle engine. Some test vehicles have used even more efficient Brayton Cycle engines.

The combined effect of these characteristics yields a large impact on emissions. The Toyota Prius achieved "Super Ultra Low Emission Vehicle" (SULEV) status when it entered North American markets in 2000. The SULEV requirements result in about $90 \%$ reduction in hydrocarbon emissions, and substantial reductions in oxides of nitrogen and even carbon dioxide.

\section{ELECTRICAL AND MECHANICAL OPPORTUNITIES}

It is well known that median daily automobile usage is less than $50 \mathrm{~km}$. Given the inherent flexibility, high efficiency, and other advantages of electric drives, there is incentive to use all-electric vehicles to satisfy most daily driving needs. Since $50 \mathrm{~km}$ usually represents a round-trip distance, a car with a range of just $40 \mathrm{~km}$ - well within the typical range of the EV1 - could cover far more than half of actual driving. From a marketing perspective, such a vehicle, with less than $10 \%$ of the range of a typical car, would be too risky. The possibilities motivate the convept 
of a "plug-in hybrid", a vehicle with electric range of 20$50 \mathrm{~km}$ and a hybrid system to deliver long range when the need arises. Such a vehicle would offload a large percentage of transportation energy to the electricity grid, with associated benefits.

Plug-in hybrids are associated with many opportunities for engineering advances in both electrical and mechanical arenas. On the electrical side, these vehicles would stimulate price-based utility metering to control electrical demand. The right process could improve load factor substantially on the grid. Other opportunities include intelligent battery chargers that could provide the longest possible battery life, intelligent grid interfaces that could allow battery energy to support a utility under emergency conditions, and system-level controls to minimize overall energy consumption. Challenges in power electronics in particular offer nearly unlimited opportunity in this context.

On the mechanical side, the flexibility, fast dynamics, and high-fidelity torque control capabilities of electric drives open many new possibilities. An early prototype [9] used fast motor control to eliminate the clutch in a manual transmission. Such a process provides an opportunity for intelligent gearboxes that enhance drive train efficiency and performance. For example, the capabilities of an electric drive are greatly extended if a three-speed gearbox is provided. Another emerging development is the integrated starter-alternator [10], in which all or part of the electric drive in a hybrid is closely coupled to the engine. Still others include opportunities when two separate drive motors are used, opportunities to incorporate flywheels, and even ways to use electric machines to counteract torque pulses from the engine [11].

Regardless of whether a vehicle is electric or hybrid, an important combined electrical and mechanical opportunity lies in increased use of electromechanical devices as part of the overall system. Electric power steering [12], water pumps, air conditioning compressors, and other major accessories enhance system efficiency while improving performance. Looking further into the future [13-16], electromechanical devices such as valve actuators will enhance the performance of engines themselves.

\section{Fuel Cell Opportunities}

Fuel cells act like "flow-through" batteries, providing an electrochemical potential when fuel (generally hydrogen) is present. Fuel cell vehicles are sometimes discussed as a long-term electric vehicle technology that overcomes the limitations of batteries. In the automotive size range, fuel cells are expected to be about $50 \%$ efficient in converting from fuel to electrical output [17]. This contrasts with the typical $20 \%$ efficiency or less in a modern car. Hybrids can improve the conventional situation by making more effective use of the engine, since a high-quality diesel engine with electric generator load can exceed $40 \%$ efficiency, But fuel cells remain of special interest because they offer the potential of carbon-free transportation processes.

Although fuel cells resemble batteries in many ways, they have distinctive characteristics unlike those of typical secondary (rechargeable) batteries. A simulated voltagecurrent characteristics for a proton-exchange-membrane (PEM) fuel cell is shown in Fig. 2. It illustrates two of the differences. First, the voltage shows wide variation over the operating range. A power converter designed for a fuel cell must cope with a 2:1 voltage range or more. Second, the curve depends on fuel flow. To use fuel effectively and achieve high efficiency, fuel delivery must be adjusted based on the electrical load.

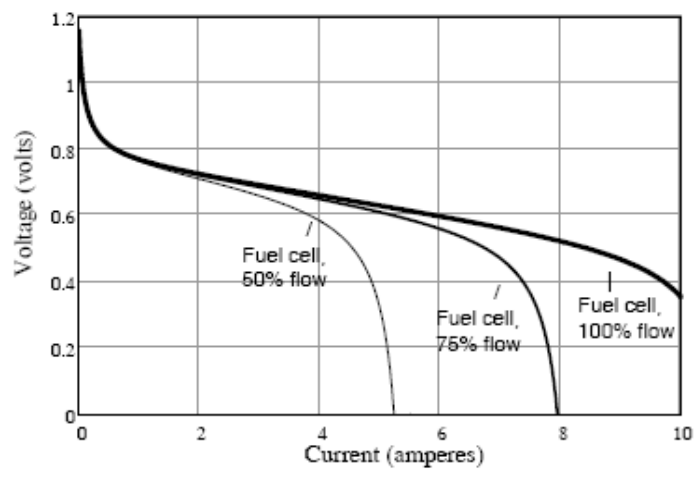

Fig.2: Typical PEM characteristics

The latter characteristic gives rise to a third major difference: practical fuel cells have slow response times, often on the order of seconds or minutes, in response to electrical load changes. In a vehicle, this means that batteries or other fast storage devices must be present to handle transients. A fuel cell vehicle thus becomes a type of hybrid car, in which a fuel cell takes the place of the engine but the rest of the system is unchanged.

The development of fuel cells continues. Many of the challenges are in materials engineering. PEM fuel cells, for example, rely on their membrane as the primary chemical exchange mechanism. Today's membranes can be compromised by impurities such as $\mathrm{CO}$ and hydrocarbons, and purity of the hydrogen fuel becomes a major limitation. Membranes that can function over the full life of a car remain a challenge.

Power electronics is a central issue for fuel cells. A converter such as the one in Fig. 3 is needed for fuel cell conversion. Like any switching converter, this circuit operates at relatively high frequency to reduce the size of the magnetic. Techniques to interface fuel cells with the batteries or capacitors needed to operate the complete system are the subject of active research at many places.

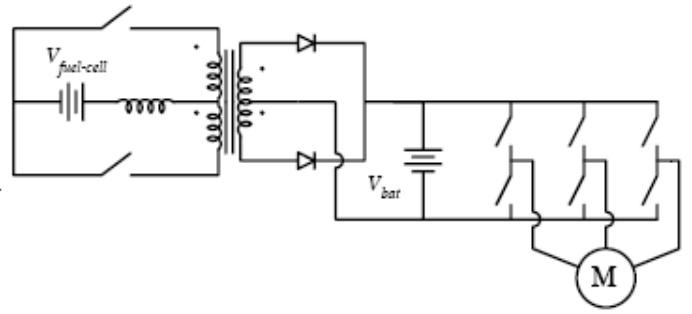

Fig. 3: Fuel cell system architecture with battery

\section{COMMERCIAL HYBRIDS}

An integrated starter-alternator (ISA) of sufficient size allows the engine to be stopped and started conveniently during stopped traffic. If the ISA is large enough to permit energy recovery during braking, the combined 
system is termed a mild hybrid [18]. The Honda Insight, the first modern hybrid car on the North American market, is considered a mild hybrid by many experts. The car, shown in Fig. 4, uses an ISA architecture to maximize fuel economy. It has a lightweight two-seat chassis.

A more sophisticated parallel hybrid system can be found in the Toyota Prius (Fig. 5) and the more recent Ford Escape hybrids [19]. In this system, the engine and primary electric machine are connected through a sunplanet gear set. This provides a degree of independence between the two energy sources.

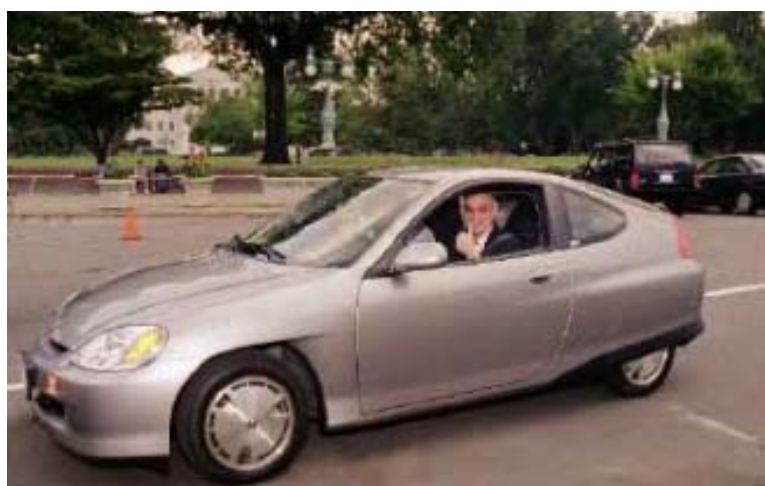

Fig.4: Honda Insight mild hybrid (from Bennett.senate.gov)

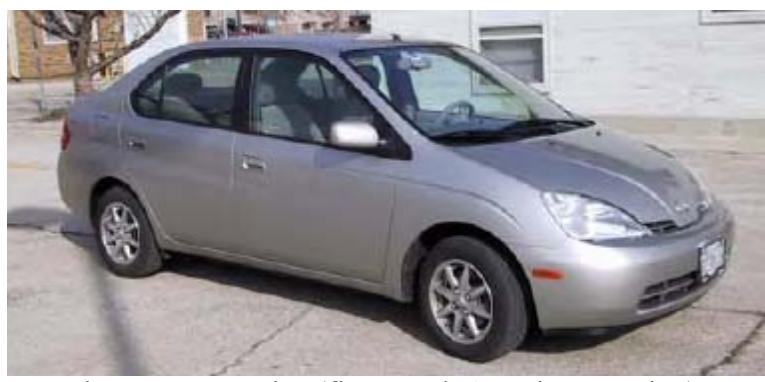

Fig.5: Toyota Prius (first North American version).

The diesel-electric drive train is an example of a series hybrid vehicle architecture. In a system of this type, the multiple energy resources are brought together in electrical form. This has the advantage of decoupling the engine from vehicle performance, since the engine drives a generator rather than an axle. The Toyota and Ford drive trains achieve a degree of operation in this regard by providing a second electric machine to serve as a generaor. Series designs offer energy source flexibility. Fuel cell vehicles, for example, are series hybrids. Turbinegenerator series hybrids have also been constructed.

\section{CONCLUSION}

Electric vehicles were common a century ago, an hybrid designs also appeared in the early 1900s. Thanks to recent innovations in power electronics and electric drives, electric and hybrid cars are reappearing. These vehicles offer significant technical challenges in electrical, mechanical, and materials engineering topics. The anticipated introduction of fuel cell cars offers opportunities for a range of technology advances. Today's hybrid cars use self-contained ISA and parallel architectures. Plug-in hybrids that support short-range driving from electrical energy are expected in the next few years.

\section{REFERENCES}

[1] P.T. Krein, "The Re-Electrification of the Automobile: Trends and Motives in Hybrid and Electric Car Designs," in Proceedings $4^{\text {th }}$ Int' 1 . Conference Electrical and Electronics Engineering, 2005.

[2] The History of Electric Cars, "The Early Years (18901930)", Idaho National Laboratory http://avt.inel.gov/pdf/fsev/history.pdf.

[3] "Ferdinand Porsche," in http://en.wikipedia.org/wiki/ Ferdinand Porsche.

[4] A Lohner-Porsche Hybrid was Displayed at the Technology Museum in Vienna, Austria in 2002. A photograph of this Vehicle, Showing the Hub Motors on the Front Wheels, is available, http://www.canadiandriver.com/articles/tw/ hybrid-history.htm.

[5] Darryl McMahon, "Some EV History," Econogics, Inc., http://econogics.com/ev/evhistry.htm

[6] P.T. Krein, M. Amrhein, "Vehicle System and Subsystem Interactions with Power Electronics," Technical Report UILU-ENG-2004-2505, CEME-TR-04-03, Engineering Documents Center, University of Illinois at UrbanaChampaign, July 2004.

[7] B. Waddell, "Personal Photograph, Uesd by Permission". Available: www.getmsm.com.

[8] M.S. Duvall, "Battery Evaluation for Plug-In Hybrid Electric Vehicle," in Proceedings. IEEE Vehicle Power and Propulsion Conference, 2005, pp. 338-343.

[9] P.T. Krein, T.G. Roethemeyer, R.A. White, B.R. Masterson, "Packaging and Performance of an IGBT-Based Hybrid Electric Vehicle,“ Proceedings IEEE Power Electronics in Transportation, pp. 47-52.

[10] W. Cai, "Comparison and Review of Electric Machines for Integrated Starter Alternator Applications," in Rec., IEEE Industry Applications Soc. Annual Meeting, 2004, pp.386393.

[11] R.I. Davis, R.D. Lorenz, "Engine Torque Ripple Cancellation with an Integrated Starter Alternator in a Hybrid Electric Vehicle: Implementation and Control," in Rec., IEEE Industry Applications Soc. Annual Meeting, 2002, pp.2016-2012.

[12] R. McCann, L.R. Pujara, J. Lieh, "Influence of Motor Drive Parameters on the Robust Stability of Electric Power Steering System," in Proceedings IEEE Workshop Power Electronics in Transportation, 1988, pp.103-108.

[13] J.G. Kassakian, "The Future of Power Electronics in Advanced Automotive Electrical System," in Rec., IEEE Power Electronics Specialists Conference, 1996, pp. 7-14.

[14] J.G. Kassakian, H.C. Wolf, J.M. Miller, C.J. Hurton, "Automotive Electrical System Circa 2005," IEEE Spectrum, Vol.33, No. 8, August 1996, pp. 22-27.

[15] J.G. Kassakian, J.M. Miller, N. Traub, "Automotive Electronics Power Up," IEEE, Spectrum, Vol. 37, No. 5, May 2000, pp. 34-39.

[16] J.G. Kassakian, D.J. Perreault, "The Future of Electronics in Automobiles," in Proceedings IEEE Int'1. Symp. Power Semiconductor Devices, 2001, pp. 15-19.

[17] J.H. Scott, "Fuel Cell Fundamentals," Presented at "The Hydrogen Economy: Its Impact on the Future of Electricity," Washington, April 2004.

[18] T. Teratani, K. Kuramochi, H. Nakao, T. Tachibana, K. Yagi, S. Abou, "Development of Toyota Mild Hybrid System (THS-M) with 42V PowerNet, in Proceedings IEEE Int"1. Machines and Drives Conference, 2003, pp. 3-10.

[19] J.M. Miller, P.J. McCleer, M. Everett, Comparative Assessment of Ultra-Capacitors and Advanced Battery Energy Storage Systems in Powersplit Electronic-CVT Vehicle Power Trains, in Proceedings IEEE Int'1. Electric Machines and Drives Conference, 2005, pp. 1513-1520. 


\title{
Novel ZVS Three-Phase PFC Converters and Zero- Voltage-Switching Space Vector Modulation (ZVS-SVM) Control
}

\author{
Dehong $\mathrm{Xu}^{1}$ and Bo Feng ${ }^{2}$
}

\begin{abstract}
In three-phase PFC converter, there exist severe switch anti-parallel diode reverse recovery problems. The effective measures of Compound Active-clamping and Minimal Voltage Active-clamping techniques in single phase PFC are extended to three-phase PFC. A family of Activeclamping ZVS soft switching PFC converter is derived. They can effectively suppress the diode reverse recovery and realize ZVS for all the switches. In order to refuce the number of switching for the auxiliary switch. A ZVS space vector modulation (ZVS-SVM) is proposed. The switching frequency of the main switch and the auxiliary switch is fixed. In the proposed circuit only one auxiliary switch is needed, which can realize ZVS for all the switches. At the same time the input current waveform is improved. One DSP controlled 4kW ZVS Compound Active-clamping PFC converter prototype is implemented.
\end{abstract}

Keywords - Three-phase PDC, zero- voltage- switching, space vector modulation

\section{INTRODUCTION}

Six-switch three-phase boost rectifier is one of the preferred topology for implementing the active inputcurrent shaping in three-phase AC-DC converter. It has several advantages such as lower current stree, high efficiency, and small input EMI filter. However, the antiparallel diodes of all the switches in the rectifier experience reverse recovery problem which will cause severe switching loss, high di/dt and EMI problems. The anti-parallel diode reverse recovery loss is one of the main losses in the six-switch boost rectifier [1].

For passing years, many works about soft switching for three-phase rectifier or inverter have been undertaken to solve the diode reverse recovery problem. The DC-rail ZVT boost rectifier proposed in [2] adopts a DC-rail diode and a ZVT branch to suppress the diode reverse recovery and to realize the ZVS of the main switches. However the auxiliary switch is hard switching. The auxiliary resonant commutated pole (ARCP) converter put the soft-switching circuit at the ac side to reduce the auxiliary circuit conduction loss and facilitate bi-directional power flow. However it needs six extra auxiliary switches to realize the soft switching [3]. The resonant dc link (RDCL) proposed in [4][5] has the simplified topology. However the switches in RDCL converter suffer from high voltage stress (about 2.5 times the output voltage). The active clamped RDCL in [6] has a low voltage stress (about

\footnotetext{
Digital ref: AI70101003

${ }^{1,2}$ College of Electrical Engineering, Zhejiang University, Hangzhou 310027, P. R. China

The paper is an invited paper to the Journal. The paper is first received in Mar 2007
}

$1.3 \sim 1.4$ times the output voltage). Instead of using PWM control, RDCL and ACRDCL converters have to use discrete pulse modulation (DPM), which normally causes undesirable sub-harmonics. DPM requires the dc-link resonating frequency to be several times higher than the switching frequency of the PWM converter for the same current spectral performance [1][6].

In this paper, the concept of Compound Active-clamping and Minimal-voltage Active-clamping [9][10] in single phase PFC is extended to three-phase PFC. A family of Active-clamping ZVS three-phase PFC is proposed. To suppress the diode reverse recovery of the three-phase switch, a novel zero voltage switching space vector modulation (ZVS-SVM) for the Active-clamping ZVS three-phase PFC is proposed. The switching frequency of both the main switches and the auxiliary switch is fixed. The switching frequency of the auxiliary switch is equal to that of the main switches. The diode reverse recovery of the switch anti-parallel diode is suppressed and all the switches can be turned on under zero voltage condition. The voltage stress on the switches is much lower than that on the RDCL and the ACRDCL converters.

A 4kW DSP (TMS320F2407A) controlled Compound Active-clamping ZVS Three-Phase PFC is built to verify the theory.

\section{NOVEL ZVS THREE-PHASE PFC CONVERTER FAMILY}

In single phase PFC converter, there also exists severe diode reverse recovery problem. In the passing years, there are many significant works to solve the diode reverse recovery problem [7]-[10]. Among them, the Compound Active-clamping (CAC) and Minimum-voltage Activeclamping (MVAC) techniques can effectively suppress the diode reverse recovery and create ZVS for both the main switch and the auxiliary switch. Fig.1 and Fig.2. show the CAC and MVAC PFC converters separately. The key ideas of these two Active-clamping soft-switching techniques are as follows:

1. An inductor is placed in series with the diode and the main switch. The inductor can suppress the diode reverse recovery and reduce the diode reverse recovery related loss.

2. A clamping branch composed of one clamping capacitor and one auxiliary switch is placed in parallel with the inductor, thus it can clamp the voltage stress of the inductor when the main switch turns off. The auxiliary circuit can also help to realize ZVS for the two switches. 


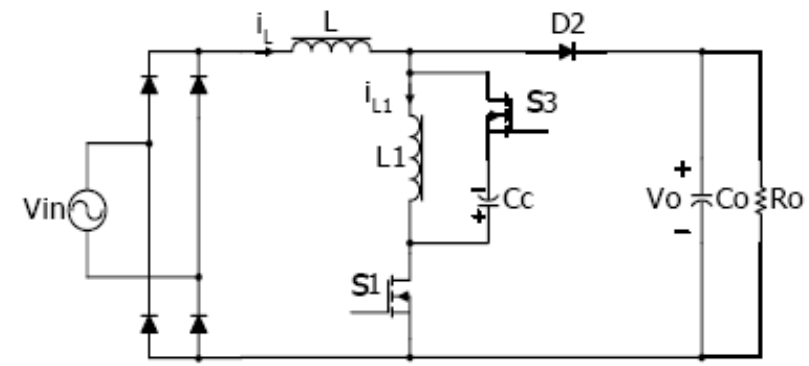

Fig.1: CAC PFC converter

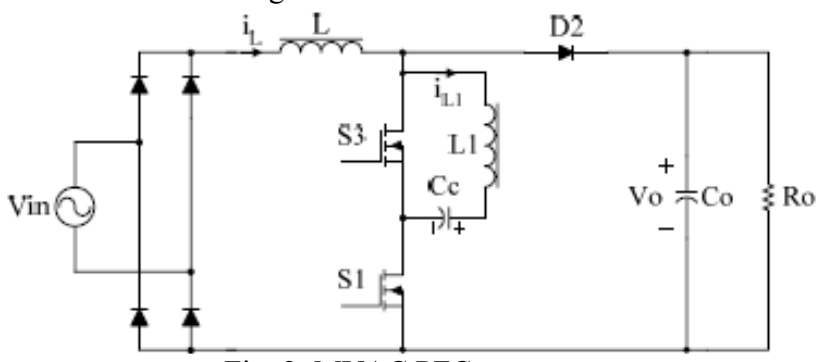

Fig. 2: MVAC PFC converter

In three-phase PFC, the diode reverse recovery problem in every phase is similar to that in single-phase PFC. Thus we extend the concept of Active-clamping techniques to three-phase PFC, and can get Compound Active-clamping three-phase PFC converters that are shown in Fig. 3 and Fig.4.

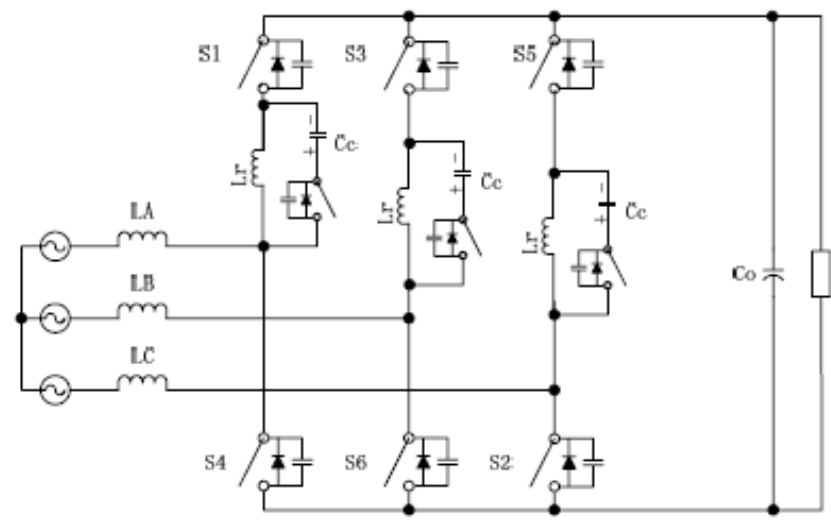

Fig. 3: CAC PFC converter (1)

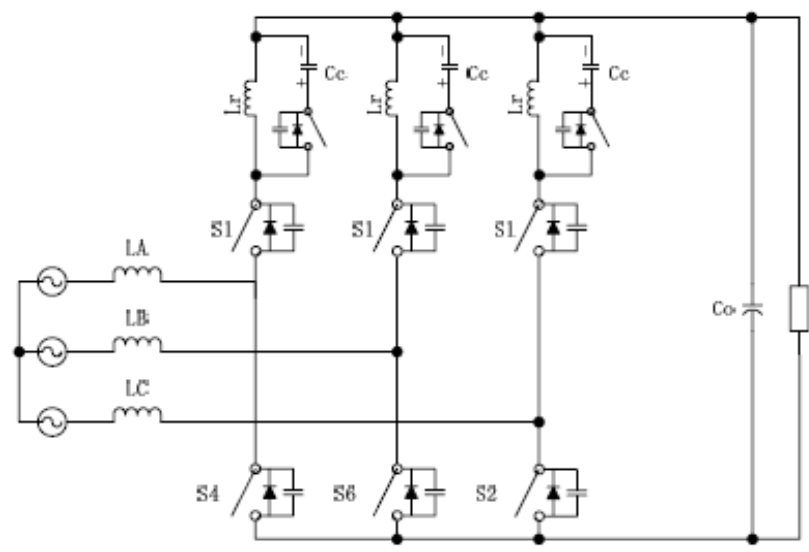

Fig. 4: CAC PFC converter (2)

These two kinds of ZVS three-Phase PFC can suppress the diode reverse recovery and realize ZVS for all the switches. However, the topology needs three extra switches.

Fig. 5 shows the CAC ZVS three-phase PFC converters, Fig. 6 shows the MVAC ZVS three-phase PFC converters.
The ZVS PDC converters in Fig. 5 and Fig. 6 use only one auxiliary switch, one resonant inductor and one clamping capacitor. Since in most time of a switching cycle, the auxiliary switch is conducting, there is generally enough energy circulating in the auxiliary branch. When the auxiliary switch is turned off, the current in the resonant inductor will discharge the parallel capacitors of the main switches, then the main switches can be turned on under zero voltage condition. When the main switches are turned on, the resonant inductor can suppress the reverse recovery current of the anti-parallel diode of the opposite switch in the same pole.

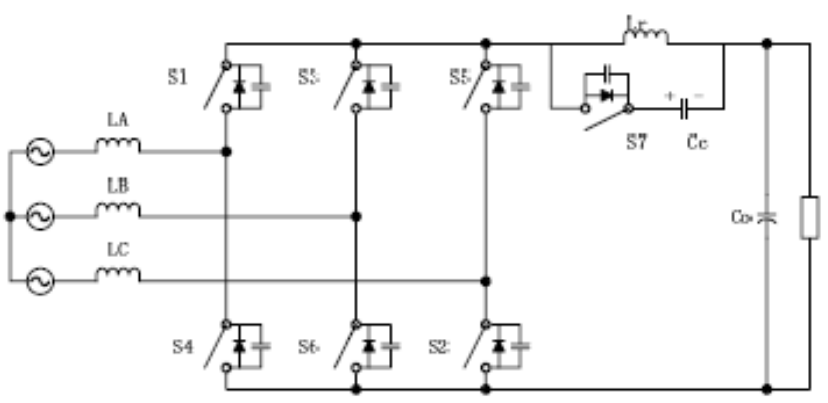

(a)

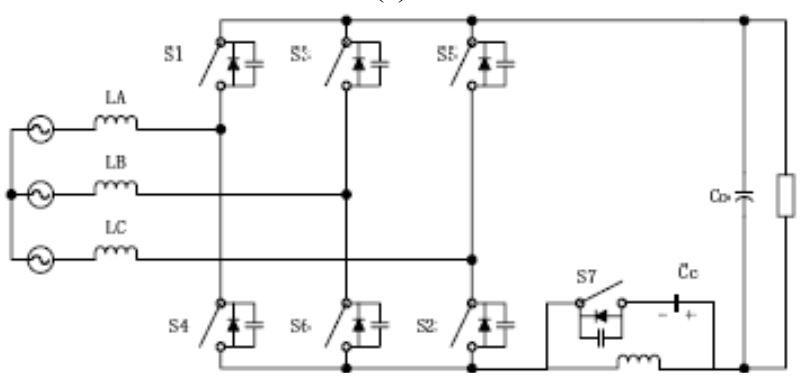

(b)

Fig. 5: CAC ZVS three-Phase PFC converters

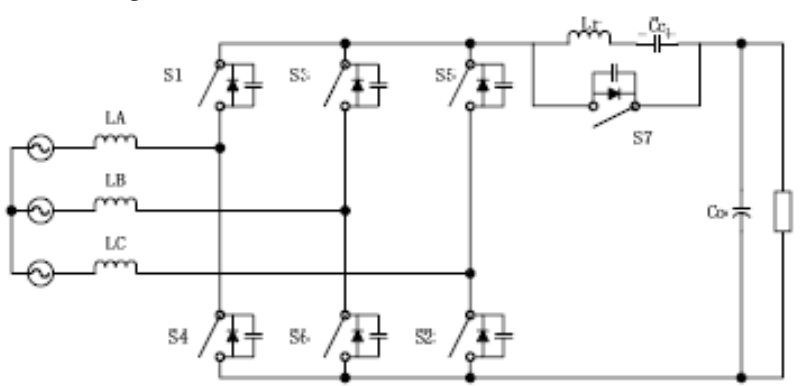

(a)

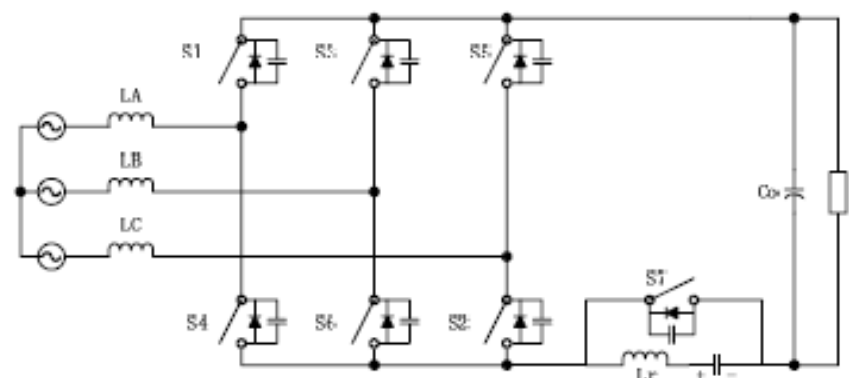

(b)

Fig. 6: CAC ZVS three-Phase PFC converters

Although the topology is the same as that of ACRDCL converter, the control pattern is quite different. To suppress the diode reverse recovery for the switches in three phase. Special control methods should be taken. In this paper, a novel Zero-Voltage-Switching Space Vector Modulation (ZVS-SVM) is proposed. Under the ZVS- 
SVM control, all the diode reverse recovery of the switch anti-parallel diodes are suppressed and all the switches can be turned on under zero voltage condition. The switching frequency of both the main switches and the auxiliary switch are fixed. The switching frequency of the auxiliary switch is equal to that of the main switches.

Among the three-phase PFC converters, the VIENNA rectifier employs only three active switches and can achieve good current quality. However there also exists severe diode reverse recovery problem that limit the switching frequency of the VIENNA rectifier. In this paper, the concepts of Compound Active-clamping and Minimal-voltage Active-clamping are extended into the VIENNA rectifier and two kinds of ZVS VIENNA rectifies are got. Fig. 7 shows the CAC ZVS VIENNA rectifier and Fig. 8 shows the MVAC VIENNA rectifier.

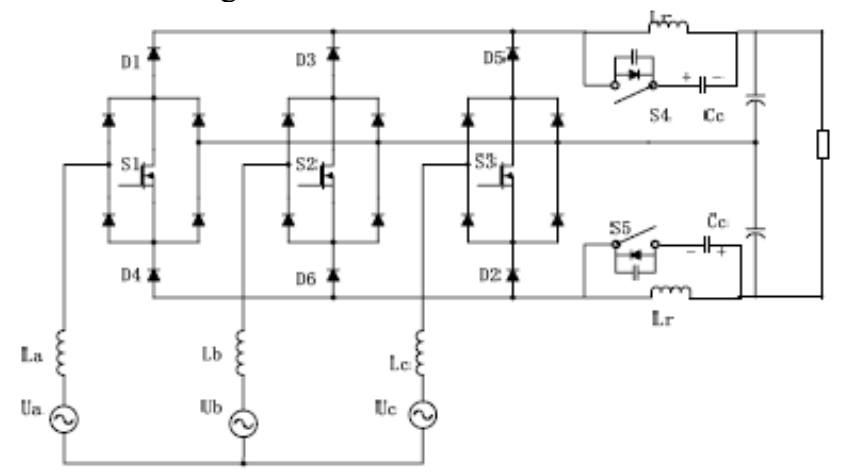

Fig. 7: CAC ZVS VIENNA rectifier

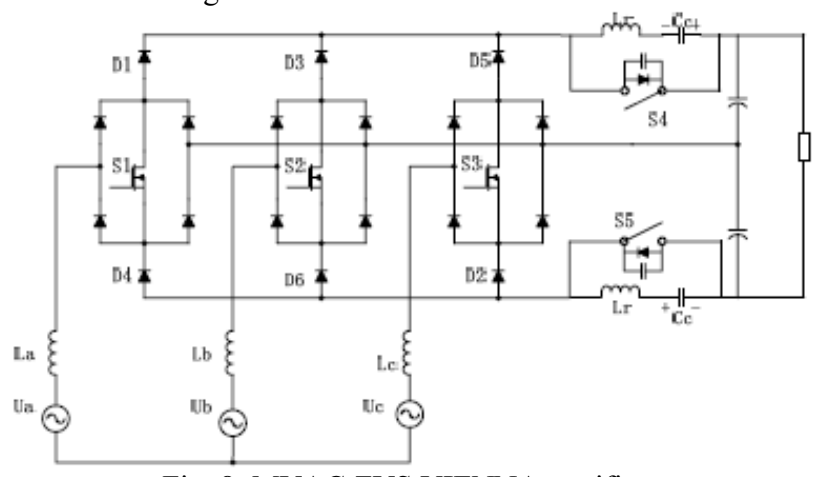

Fig. 8: MVAC ZVS VIENNA rectifier

\section{Zero Voltage Switching Space Vector MODULATION (ZVS-SVM)}

In space vector modulation scheme, the phase voltage waveform and voltage space vector definition are shown in Fig. 9. V0 to V7 are the eight different switching states in the converter operation. In ZVS SVM, the whole utility cycle is divided into 12 sectors.

In three-phase PFC, since there are three legs in the main bridge, the auxiliary switch must be activated three times per switching cycle if the switches in the three legs are modulated asynchronously. Actually in one sector the switch states of the phase with the highest current is fixed, only other two phases need to be considered about the diode reverse recovery suppressing and ZVS condition. If the switches in the other two phases are so controlled that the turn on time of the other two phase switches is synchronized, the diode reverse recoveries of them can be coped with at the same time. Thus the auxiliary switch need only to operate once in one switching cycle to resonant the DC bus to zero and create ZVS condition for the two phase switches and suppress the diode recoveries of both phases. Thus the auxiliary switch can work at the same frequency with the main switches.

Since the operation of the converter is symmetrical in every $30^{\circ}$, to understand the operation of the circuit, we assume that the converter is operating in sector 2 as an instance where input current $\mathrm{Ia}>0, \mathrm{Ic}<0$ and $\mathrm{Ib}<0$. There are three switch states in one switching cycle, as shown in Fig. 10. The three switch states are state 100, state 111 and state 110 . The equivalent circuits of these three states are shown in Fig. 11. In this sector, phase A has the highest input voltage and the highest input current. Switch $\mathrm{S} 1$ is always on while switch S4 is always off in sector 2 . The switches in the other two phases are controlled in the PWM manner. According to the proposed ZVS-SVM scheme, the switch S3 and S5 are to be turned on simultaneously when switching state 100 changes to state 111.

In state 100, although the driving singles of S1, S6 and S2 are effective, it is the anti-parallel diodes of S1, S6 and S2 being conducting. If the rectifier state is changing from 100 to 111, switch S3 and S5 will starts to conduct while the anti-parallel diodes of S6 and S2 will turn off. During the commutation from the lower-leg diodes to the upperleg diodes to the upper-leg switches there exist diode reverse recovery problems. In state 100, switch S7 is conducting and the current in the resonant inductor $\mathrm{Lr}$ is increasing. The energy stored in the resonant inductor can help to realize ZVS for both switch S3 and S5 in the transition from state 100 to 111 .

In state 111 , the energy in the input inductor is increasing while the current in the resonant inductor $\mathrm{Lr}$ is charging the clamping capacitor Cc. Later the current in Lr changes its direction.

In he state transition from 111 to 110 , switch S5 is turned off, the current in input inductor Lc will charge S5's paralleled capacitor and discharge S2's paralleled capacitor. Thus S5 is ZVS turned off. Once the voltage on S5 decrease to zero, S2's anti-parallel diode starts to conduct. Therefore the current naturally transfers from S5 to S2's anti-parallel diode.

In the state transition from 110 to $100, \mathrm{~S} 3$ is turned off, the current in input inductor Lb will charge S3's paralleled capacitor and discharge S6's paralleled capacitor. Thus S3 is ZVS turned off. Once the voltage on S3 decrease to zero, S6's anti-parallel diode starts to conduct. Therefore the current naturally transfers from S3 to S6's antiparallel diode.

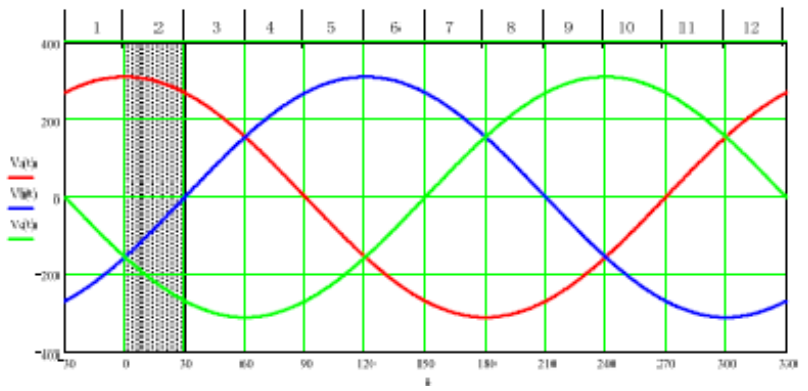




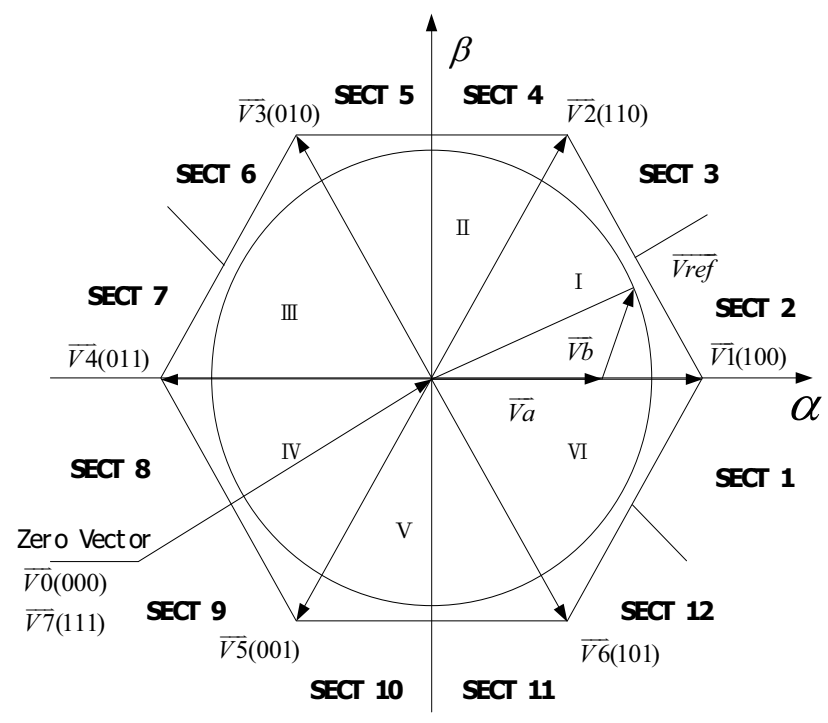

Fig. 9: Three-phase voltages and voltage space vectors

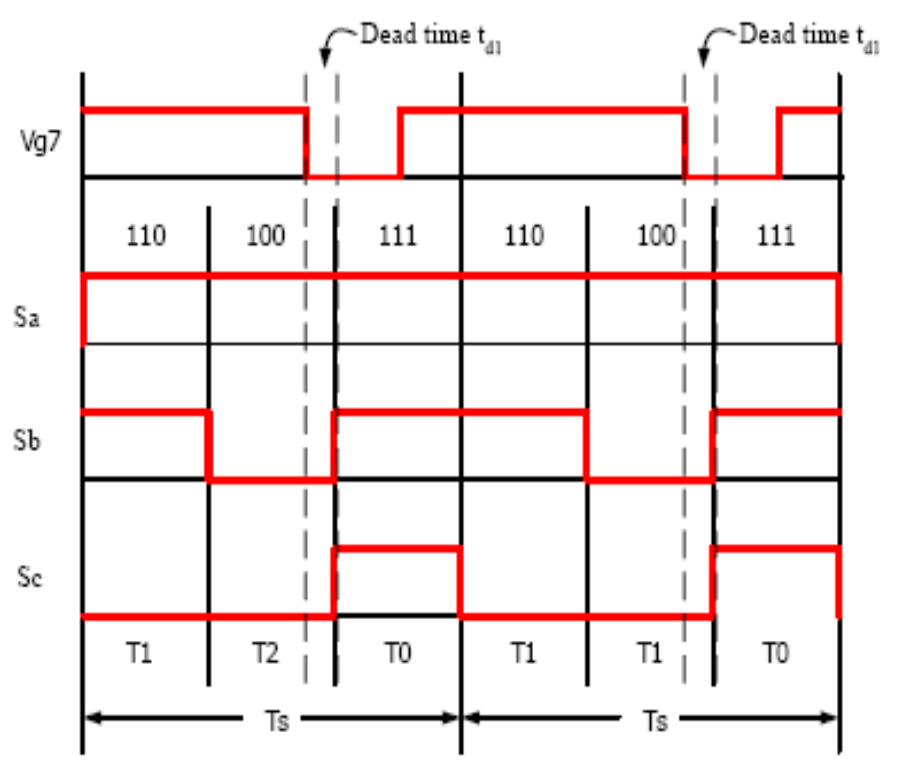

Fig. 10: switching sequence in sector 2: 100-111-110-100

Thus with the ZVS-SVM control the ZVS Activeclamping three-phase PFC can realize ZVS for all the switches and suppress all the diode reverse recovery. The switching frequency of the auxiliary switch is equal to that of the main switch.

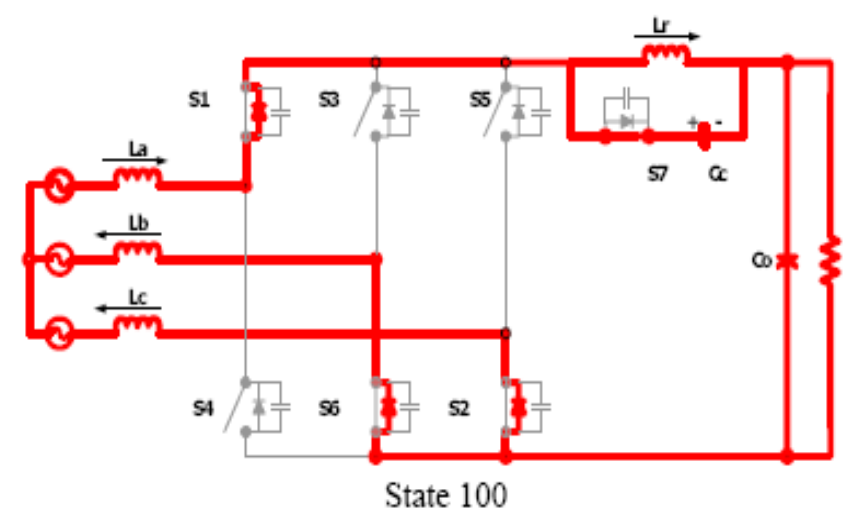

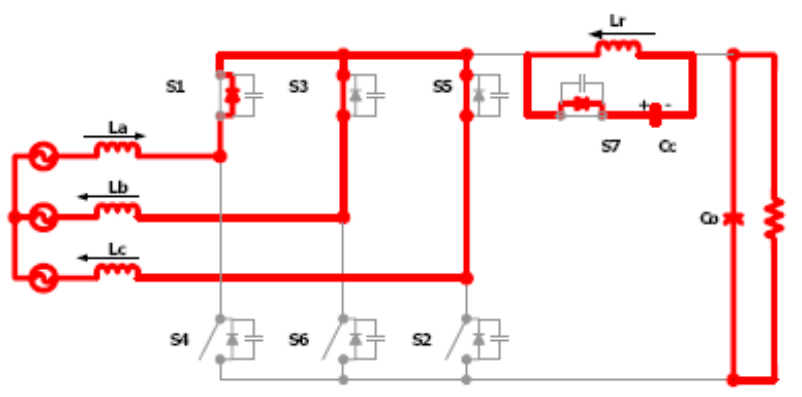

State 111

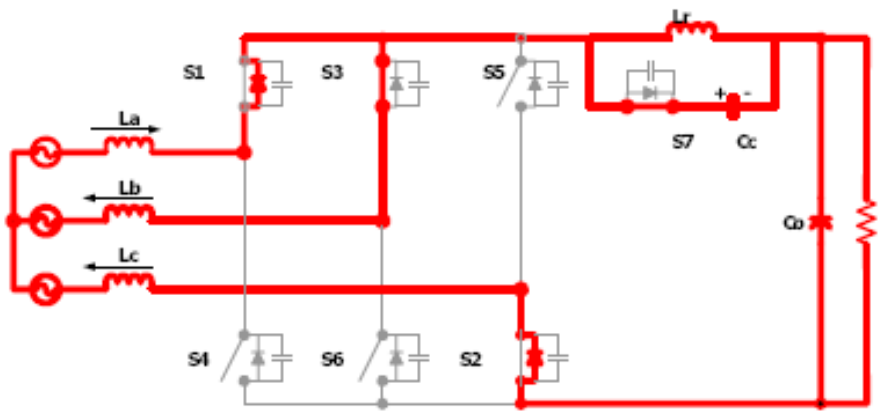

State 110

Fig. 11: operation stages of three switching states

\section{TheORETICAL ANALYSIS OF CAC ZVS ThreE-PhASE PFC CONVERTER}

In this paper, we take the Compound active-clamping threphase PFC converter as an example to do the theoretical analysis. Since in the ZVS-SVM control the operation of the converter is symmetrical in every $30^{\circ}$, we still take sector 2 as an example to analyze.

The following assumptions are made to simplify the analysis of the proposed CAC PFC converer:

- The capacitances C1 to C6 paralleled with main switches S1 to S6 respectively include parasitic capacitance and external capacitance. The capacitance $\mathrm{C} 7$ paralleled with the auxiliary switch S7also includes parasitic capacitance and external capacitance.

- The input filter inductors L1, L2, L3 are so large that their currents can be considered as constant current source in one switching cycle.

- The output filter capacitor $\mathrm{C}_{\mathrm{o}}$ is represented by a constant voltage source.

- The value $\mathrm{C}_{\mathrm{c}}$ is large enough so that the voltage can be seen as a constant.

- The resonant frequency of $\mathrm{C}_{\mathrm{c}}$ and $\mathrm{L}_{\mathrm{r}}$ is much lower than the operation frequency of the converter.

The steady-stage and key waveforms of the CAC ZVS three-phase PFC are shown in Fig. 12 and Fig. 13 respectively. The switching cycle can be divided into 8 stages.

Stage 1 (t0-t1): In this stage, S1, S2, S6 and the auxiliary switch S7 is on. The energy in input inductor is sending to the output. The current in resonant inductor Lr increases at the rate of 
$\frac{d i_{L r}}{d t}=\frac{V_{C c}}{L r}$

Stage 2(t1-t2): In t1, S7 is turned off, the resonant inductor Lr will discharge the main switch S3, S5, S4's paralleling capacitors $\mathrm{C} 3, \mathrm{C} 4, \mathrm{C} 5$. At time $\mathrm{t} 2$, the voltages on these capacitors decrease to zero and the anti-parallel diode of these main switches start to conduct. Then S3 and S5 can be turn on with zero voltage switching. At time $t 2$ the voltage on $\mathrm{S} 7$ reaches $\mathrm{V}_{\mathrm{O}}+\mathrm{V}_{\mathrm{Cc}}$.

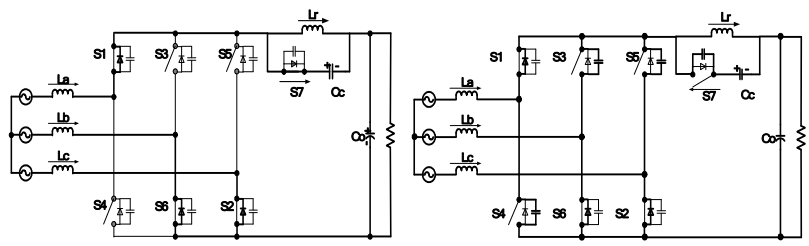

stage1 ( $\mathrm{t} 0-\mathrm{t} 1)$

stage2(t1-t2)

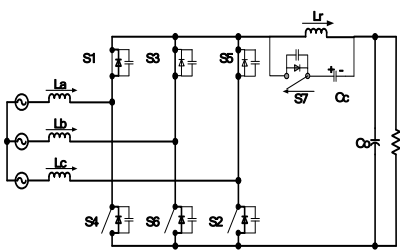

stage $3(\mathrm{t} 2-\mathrm{t} 3)$

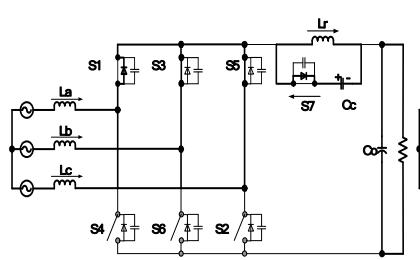

stage5 (t4-t5)

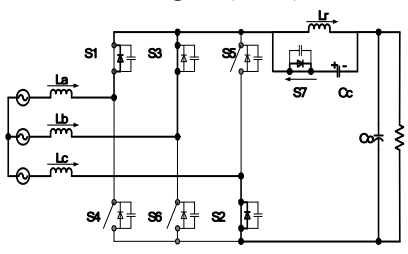

stage7 (t6-t7)

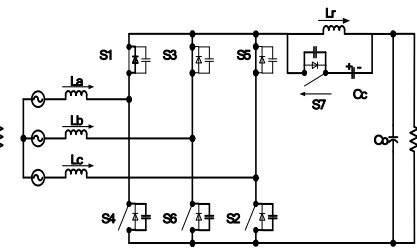

stage4 (t3-t4)

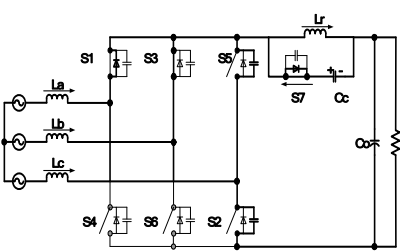

stage6 (t5-t6)

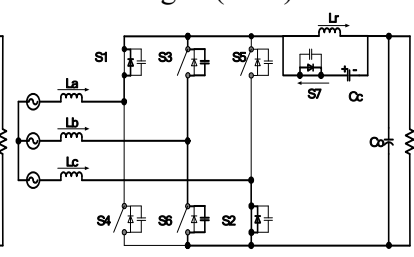

stage8 ( $\mathrm{t} 7-\mathrm{t} 8)$
Fig. 12: operation stages of CAC ZVS PFC

Stage 3 (t2-t3): From this stage, the anti-parallel diode of S6 and S2 experience diode reverse recovery. Due to the existence of the resonant inductor $\mathrm{Lr}$, the diode reverse recovery is suppressed. At time $\mathrm{t} 3$, the current of the antiparalleled diodes of both switch S6 and S2 drop to zero.

Stage 4 (t3-t4): At $\mathrm{t} 3$, the voltage on $\mathrm{S} 6$ and $\mathrm{S} 2$ start to rise. Lr, C2, C6 and $\mathrm{C} 7$ start to resonance. The voltage on $\mathrm{S} 7$ starts to decrease. At $\mathrm{t} 4$, the voltage on $\mathrm{S} 7$ decrease to zero, and the anti-parallel diode of S7 start to conduct. S7 can be ZVS turn on.

Stage 5 (t4-t5): At $\mathrm{t} 4$, the diode reverse recovery process completes. The circuit enters the state 111 . The main switch S1, S3, S5 and the auxiliary switch S7 are on. The resonant inductor is charging the clamping capacitor $\mathrm{Cc}$.

Stage 6 (t5-t6): At $\mathrm{t} 5$, the main switch $\mathrm{S} 5$ is turned off. Since the existence of C5 and C2, it is ZVS turn off. The input inductor Lc will charge C5 and discharge C2.
Stage 7 (t6-t7): At t6, the voltage on S2 decrease to zero, the anti-parallel diode starts to conduct. S2 can be ZVS turn on. The circuit enters state 110. The lasting time is decided by the SVM control.

Stage 8 (t7-t8): At $\mathrm{t} 7$, the main switch S3 is turned off, since the existence of $\mathrm{C} 3$ and C6, it is ZVS turn off. The input inductor $\mathrm{Lb}$ will charge $\mathrm{C} 3$ and discharge $\mathrm{C} 6$. At $\mathrm{t} 8$, the voltage on S6 decrease to zero, the anti-parallel diode starts to conduct. S6 can be ZVS turn on. The circuit enters state 100. After t8, the next switching cycle starts again.

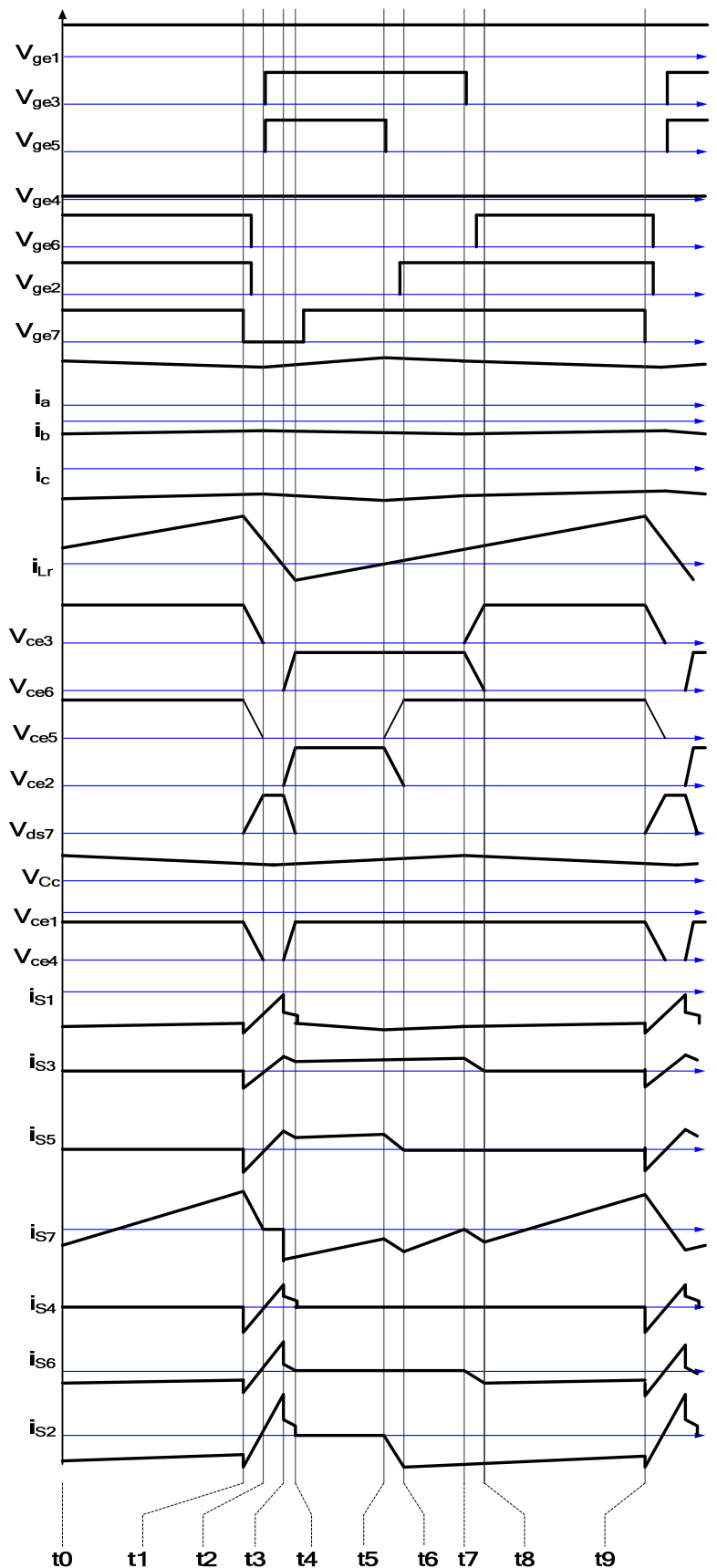

Fig. 13: Steady-state waveforms of the proposed converter

\section{TheOretical ANAlysis of CAC ZVS ThreE-PhASE PFC CONVERTER}

In every switching cycle there are three switching states, if we still take sector 2 as an example, the three states are 100-111-110. The duration of the three states can be 
expressed as $\mathrm{T} 1, \mathrm{~T} 0$, and $\mathrm{T} 2$, where $\mathrm{T}$ is the operation period.

$T_{1}=\sqrt{3} \frac{\left|U_{r f}\right|}{E_{d c}} T \sin \left(\frac{\pi}{3}-\theta_{r}\right)$

$T_{2}=\sqrt{3} \frac{\left|U_{r f}\right|}{E_{d c}} T \sin \theta_{r}$

$T_{0}=T-T_{1}-T_{2}$

\section{A. Voltage stress on the switches}

The maximum voltage stresses on the switches is

$V_{\text {max }}=V_{o}+V_{C c}$

$=V_{o}+\frac{L_{r}\left(I_{a} T_{1}+\left|I_{c}\right| T_{2}+V_{o} \sqrt{\frac{3 C+C_{7}}{L_{r}}}\right)}{T}$

In sector 2, the voltage stresses on the switches vs. the output voltage are shown in Fig.. The switch voltage stresses are only a little higher than the output voltage.

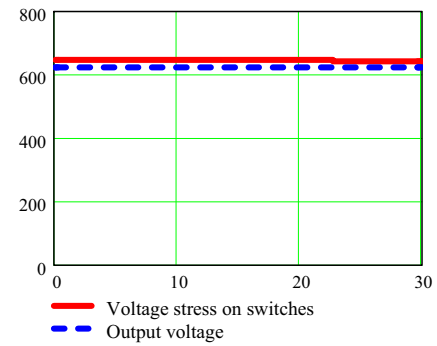

Fig.14: Voltages stress on switches vs. output voltage

\section{B. Soft switching condition}

The auxiliary switch is always zero-voltage turn-on condition. However the main switches satisfy zero-voltage turn-on condition when there is enough energy stored in resonant inductor to discharge the paralleling capacitor of the main switches. The zero-voltage switching condition for the main switch is:

$$
\begin{aligned}
2 I_{a} \frac{T_{1}}{T}+2\left|I_{c}\right| \frac{T_{2}}{T}-I_{a}-\frac{K \cdot}{V_{C E(o n)}} \cdot T>0 & \begin{array}{r}
L_{r} \\
(0<k<1)
\end{array}
\end{aligned}
$$

Where Vce(on) is the conduction voltage drop of the auxiliary switch. It is easy to achieve soft switching in the ZVS-SVM scheme.

\section{EXPERIMENTAL RESULTS}

A $4 \mathrm{~kW}$ prototype of the ZVS-SVM controlled CAC PFC converter, as shown in Fig.5 (a), is built to verify the theory, which is controlled by DSP (TMS320F2407A). The parameters of the circuit are: phase voltage Vin $=220 \mathrm{Vac}$, output voltage $\mathrm{Vo}=620 \mathrm{Vdc}, \mathrm{L}=12 \mathrm{mH}$, $\mathrm{Lr}=80 \mu \mathrm{H}, \mathrm{Cc}=45 \mu \mathrm{F}$. The parallel capacitors of the switches are $\mathrm{C} 1=\mathrm{C} 2=\ldots=\mathrm{C} 7=2 \mathrm{nF}$. The operation frequency $\mathrm{f}=12.8 \mathrm{kHz}$. The main switches, $\mathrm{S} 1 \sim \mathrm{S} 6$ : IRGPH50K. The auxiliary switch S7: CT60AM-20F.

Fig. shows the input voltage and the input current. The harmonic spectrum of the input current is shown in Fig..
The measured Power factor is 0.998 and the THD is $3.295 \%$

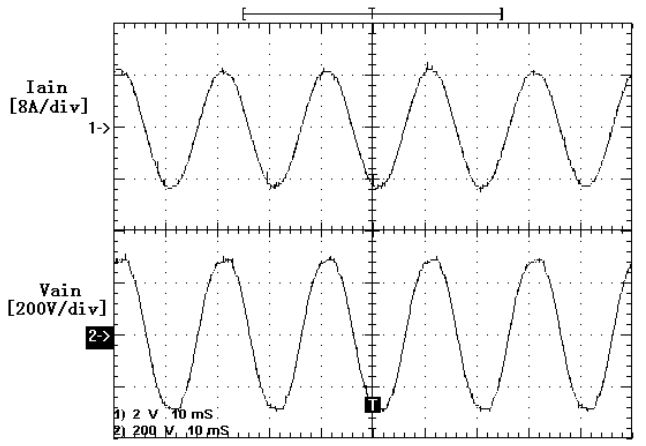

Fig.15: Input voltage and current

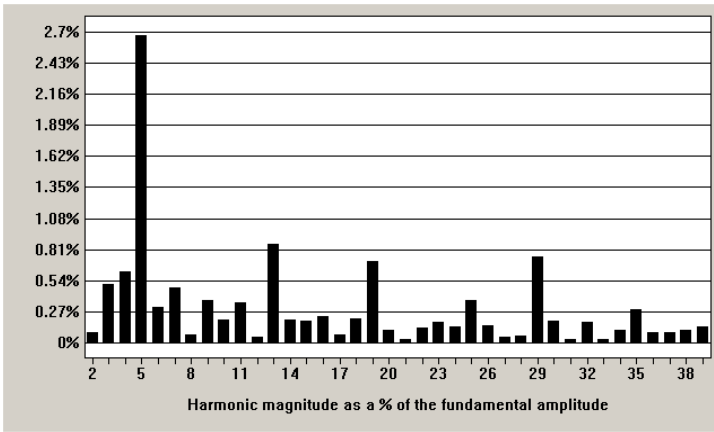

Fig.16: Input voltage and current

The CE voltage and the driving signal of the main switch and the auxiliary switch are shown in Fig. 17 and Fig. 18 respectively. As can be seen that the $\mathrm{CE}$ voltage drop to zero before the driving signal turn high. Thus both the main switch and auxiliary switch is ZVS turn on.

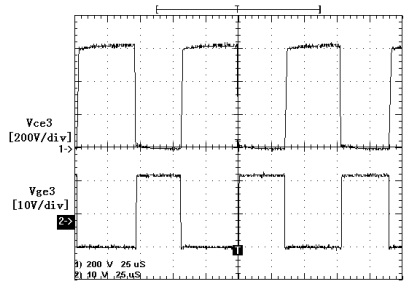

(a) time $25 \mu \mathrm{s} / \mathrm{div}$

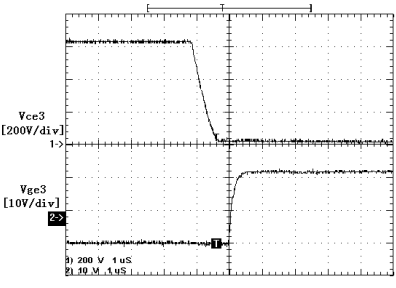

(b) time $1 \mu \mathrm{s} / \mathrm{div}$

Fig. 17: CE voltage and driving signal on main switch S3

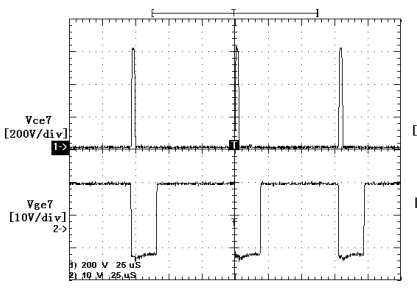

(a) time $25 \mu \mathrm{s} / \mathrm{div}$

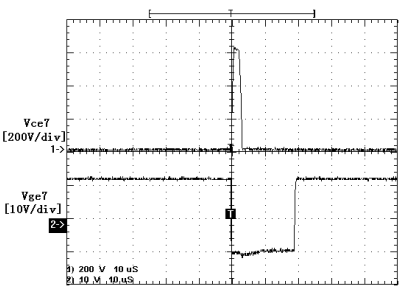

(b) time $1 \mu \mathrm{s} / \mathrm{div}$
Fig18: CE voltage and driving signal on auxiliary switch S7

The clamping voltage on the clamping capacitor is less than 40V, as shown in Fig.. Thus the voltage stress of the switches in the proposed rectifier is only about $660 \mathrm{~V}$ $\left(\mathrm{V}_{\mathrm{O}}+\mathrm{V}_{\mathrm{Cc}}\right)$. So the voltage stress is lower. 


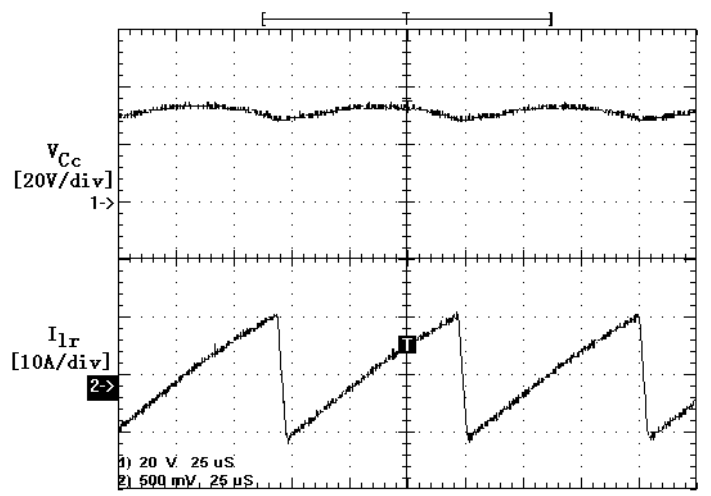

Fig. 19: Current of $\mathrm{Lr}$ and voltage on clamping capacitor

The efficiency of the ZVS PFC rectifier is shown in Fig. 20. The efficiency of a hard switching counterpart is also shown in Fig. 20.

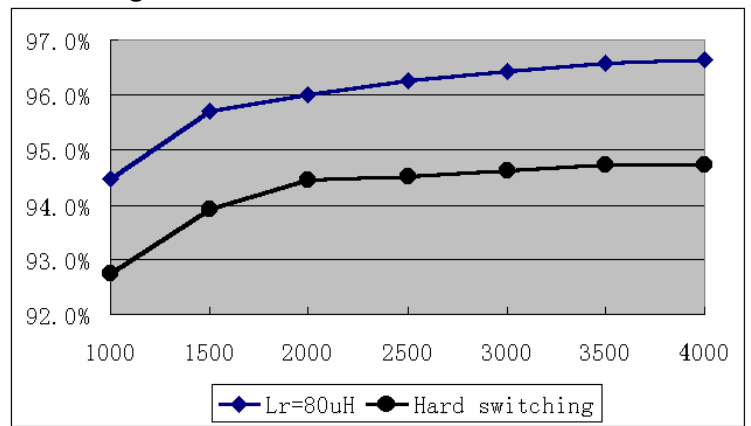

Fig. 20: Current of Lr and voltage on clamping capacitor

\section{CONCLUSION}

A family of Active-Clamping ZVS Three-Phase PFC is proposed. A specially designed ZVS-SVM for the soft switching PFC converter is proposed too. It can suppress all the diode reverse recovery, meanwhile creating softswitching condition for both the main switches and the auxiliary switch. The switching frequency is fixed, and the auxiliary switch works at the same frequency with other switches, thus the rectifier can work at higher frequency.
The voltage stress in the Active-clamping ZVS ThreePhase PFC is lower. It is suitable for high-density rectifier application.

\section{ACKNOWLEDGMENT}

The authors would like to thank the support of China Natural Science Foundation (50237030).

\section{REFERENCES}

[1] H. Mao, F.C. Lee, D. Boroyevich, S. Hiti, "Review of HighPerformance Three-Phase Power-Factor Correction Circuits," IEEE Transactions on Industrial Electronic, Vol. 44, No. 4, August 1997, pp. 437-446.

[2] Y. Jiang, H. Mao, F.C. Lee and D. Borojevic, "Simple High Performance Three-Phase Boost Rectifiers," Proceedings of PESC' 94, pp. 1158-1163.

[3] R.W. De Doncker and J.P. Lyons, "The Auxiliary Commutated Resonant Pole Converter," Proceedings of ISA' 90, pp. 1228-1235.

[4] D.M. Divan, "The Resonant DC-Link Converter- A New Concept in Power Converter," Proceedings of IAS' 86, pp. 648-656.

[5] D.M. Divan, and G. Skibinski, "Zero Switching Loss Inverters for High Power Applications," Proceedings of IAS' 87, pp. 627-634.

[6] G. Venkataramanan, D.M. Divan and T. Jahns, "Discrete Pulse Modulation Strategies for High Frequency Inverter System," Proceedings of PESC' 89, pp 1013-1020.

[7] G. Hua, C. S. Leu, Y. Jiang and F.C. Lee, "Novel ZeroVoltage-Transition PWM Converters," IEEE Transactions Power Electronics, Vol. 9, No. 2, 1994, pp. 213-219.

[8] Clàudio Manoel da Cunha Duarte and Ivo Barbi, "A New Family of ZVS-PWM Active-Clamping DC-to-DC Boost Converter: Analysis, Design and Experimentation," IEEE Transactions Power Electronics, Vol. 12, No. 5, September 1997, pp. 824-831.

[9] B. Feng, D. Xu, "1 KW Compound Active Clamping PFC Converter," Proceedings of IEEE PESC' 03, pp. 1691-1696.

[10] B. Feng, D. Xu, "1 KW PFC Converter with MinimunVoltage Active-Clamping," Proceedings of IEEE APEC' 04, pp. 1220-1125. 